p-ISSN: 2308-4944 (print) e-ISSN: 2409-0085 (online)

Year: 2017 Issue: 12 Volume: 56

Published: $30.12 .2017 \quad$ http://T-Science.org
$\mathrm{PhD}$, Deputy head of the Department of Science of

Svetlana Ivanovna Izaak
Deputy head of the Department of Science of
the Russian University of Transport (MIIT),
Moscow, Russia
e-sepp@yandex.ru
Vyacheslav Dmitrievich Mironov

Svetlana Ivanovna Izaak
Department of Science of
ersity of Transport (MIIT),
Moscow, Russia
e-sepp@ yandex.ru
slav Dmitrievich Mironov

Svetlana Ivanovna Izaak
Department of Science of
ersity of Transport (MIIT),
Moscow, Russia
e-sepp@yandex.ru
Slav Dmitrievich Mironov

$\mathrm{PhD}$,

Head of the Department of the Russian University of Transport (MIIT), Moscow, Russia

SECTION 19. Management. Marketing. Public administration.

\title{
MONITORING PATRIOTIC EDUCATION OF CHILDREN, ADOLESCENTS AND YOUTH IN THE RUSSIAN FEDERATION
}

Abstract: In the article it is shown that from the position of the management theory, activity in the sphere of patriotic upbringing is viewed as a set of techniques and methods of targeted influence of the management subject (organizational structures of the public sector, business community and civil society institutions) on the management object (different socio-demographic groups of the population) in order to achieve a certain result (education of patriotism). It is noted that the forms and methods of patriotic upbringing that have proved successful in the regions take into account the dynamically changing situation, age characteristics of citizens, as well as the need for active interdepartmental, intersectoral interaction and public-state partnership.

Key words: patriotic education, patriotism, physical culture and sports activity, management, public-state interaction.

Language: Russian

Citation: Izaak SI, Mironov VD (2017) MONITORING PATRIOTIC EDUCATION OF CHILDREN, ADOLESCENTS AND YOUTH IN THE RUSSIAN FEDERATION. ISJ Theoretical \& Applied Science, 12 (56): 134-145.
Soi: $\underline{\text { http://s-o-i.org/1.1/TAS-12-56-22 }}$
Doi: crossef https://dx.doi.org/10.15863/TAS.2017.12.56.22

\section{МОНИТОРИНГ СОСТОЯНИЯ ПАТРИОТИЧЕСКОГО ВОСПИТАНИЯ ДЕТЕЙ, ПОДРОСТКОВ И МОЛОДЕЖИ В РОССИЙСКОЙ ФЕДЕРАЦИИ}

\begin{abstract}
Аннотация: В статье показано, что с позиции теории управления деятельность в сфере патриотического воспитания рассматривается как совокупность приемов и методов иеленаправленного воздействия субъектов управления (организационных структур государственного сектора, бизнессообщества и институтов гражданского общества) на объект управления (различные социальнодемографические группь населения) с иелью достижения определенного результата (воспитание патриотизма). Отмечается, что успешно зарекомендовавшие себя в регионах формы и методы работы по патриотическому воспитанию учитывают динамично меняюшуюся ситуацию, возрастные особенности граждан, а также необходимость активного межведомственного, межотраслевого взаимодействия и общественно-государственного партнерства.

Ключевые слова: патриотическое воспитание, патриотизм, физкультурно-спортивная деятельность, управление, общественно-государственное взаимодействие.
\end{abstract}

\section{Introduction}

События последнего времени подтверждают необходимость повышения эффективности деятельности в сфере патриотического воспитания [12]. Патриотизм как социальное явление - нравственная основа существования и развития любого государства, важный внутренний ресурс развития общества и активной гражданской позиции личности [10].

Провозглашение патриотических ценностей стало неотъемлемой частью государственной политики [11]. Российская государственная политика в сфере патриотического воспитания направлена на создание условий для формирования гражданской ответственности за судьбу страны; «повышения уровня консолидации общества для решения задач обеспечения национальной безопасности и устойчивого развития Российской Федерации; укрепления чувства сопричастности граждан к великой истории и культуре России; обеспечения преемственности поколений 
россиян; воспитания гражданина, любящего свою Родину и семью, имеющего активную жизненную позицию» [1].

C позиции теории управления деятельность в сфере патриотического воспитания рассматривается как совокупность приемов и методов целенаправленного воздействия субъектов управления (организационных структур государственного сектора, бизнессообщества и институтов гражданского общества) на объект управления (различные социально-демографические группы населения) с целью достижения определенного результата (воспитание патриотизма). Эта деятельность зависит от уровня развития нормативноправового, материально-технического, научнометодического, пропагандистского обеспечения и др. Совершенствование управленческой деятельности можно рассматривать как внедрение современных форм работы, направленных на повышение вовлеченности граждан в систему патриотического воспитания. Содержание форм работы возможно изучить на основе данных мониторинга состояния патриотического воспитания в субъектах Российской Федерации.

\section{Materials and Results}

Материалы исследования составили нормативно-правовые акты и научнометодическая литература по проблеме; формы официальной статистической и описательной отчетности за 2016 г.; результаты опроса государственных органов исполнительной власти субъектов Российской Федерации в области физической культуры и спорта $[6,7,21]$.

Мониторинг - это регулярное наблюдение за развитием и изменением какого-либо процесса, состояния, явления [4, 13]. Мониторинговые исследования позволяют изучить состояние объекта в целом на основе данных, полученных в ходе сбора (регистрации), хранения и анализа ключевых (количественных или качественных) параметров рассматриваемого объекта [9, 8]. Результат - принятие адекватных решений по проблемам, выявленным в результате мониторинга [3].

Мониторинг состояния патриотического воспитания в соответствии с целевой направленностью исследования проводился на основе данных 30 субъектов 7 Федеральных округов, систематизированных по организационным формам военнопатриотической и спортивно-патриотической направленности (Таблицы 1-6).

По данным проведенного мониторингового исследования основными субъектами управленческого процесса патриотического воспитания (в аспекте военно-патриотической и спортивно-патриотической направленности) наряду с бизнес-структурами являются следующие организационно-управленческие структуры:

1) федеральные и региональные органы исполнительной власти и органы власти муниципальных образований (МО), реализующие политику в соответствующих сферах жизнедеятельности человека: военной (внутренней и внешней), правоохранительной, образовательной, молодежной, спортивной и др.; государственные учреждения, организации, предприятия, деятельность которых связана с патриотическим воспитанием;

2) общественно-государственные и общественные объединения (в том числе организации), общественные движения, осуществляющие деятельность в пределах конкретной территории: федерации, ассоциации, союзы по видам спорта; Общероссийская общественно-государственная организация «Добровольное общество содействия армии, авиации и флоту России» (ДОСААФ России); Общественно-государственное объединение (ОГО) "Всероссийское физкультурно-спортивное общество «Динамо»" (ВФСО «Динамо»); Общественно-государственное физкультурноспортивное объединение «Юность России» (ОГФСО «Юность России»); Общероссийская общественная организация "Всероссийское добровольное общество «Спортивная Россия»" (ВДО «Спортивная Россия»); Всероссийское общественное движения «Волонтеры Победы» (ВОД «Волонтеры Победы»); Всероссийское детско-юношеское общественное движение «Школа безопасности» (ВДЮОД «Школа безопасности»); Общероссийская общественная организация «Российский союз ветеранов Афганистана» (РСВА); Всероссийская общественная организация ветеранов «БОЕВОЕ БРАТСТВО»; военно-патриотические объединения и др.

Деятельность по патриотическому воспитанию регламентируется основными нормативно-правовыми актами, которыми являются: Конституция Российской Федерации; Федеральный закон от 28.03.1998 № 53-Ф3 «О воинской обязанности и военной службе» [19], Федеральный закон от 12.01.1995 № 5-Ф3 «О ветеранах» [16]; Федеральный закон от 13.03.1995 № 32-Ф3 «О днях воинской славы и памятных датах России» [17]; Федеральный закон от 19.05.1995 № 80-Ф3 «Об увековечении Победы советского народа в Великой Отечественной Войне 1941-1945 годов» [18]; Федеральный закон от 29.12.2012 № 273-Ф3 «Об образовании в Российской Федерации»; Федеральный закон от 04.12.2007 № 329-Ф3 «О физической культуре и 
спорте в Российской Федерации» [20] и иные документы правового характера.

Формы работы по патриотическому воспитанию в субъектах Российской Федерации. В соответствии с положениями федеральных законов, а также документов стратегического планирования и программирования, в регионах и муниципальных образованиях проводится систематическая работа по патриотическому воспитанию детей, подростков и молодежи [2].

Особое внимание уделяется допризывной и призывной молодежи. Многочисленные формы работы с этой категорией лиц направлены на обеспечение их готовности к защите Родины, повышение престижа службы в Вооруженных Силах Российской Федерации, совершенствование показателей физического здоровья. В связи с этим на территориях ежегодно проводятся комплексные мероприятия, имеющие военно-патриотическую и физкультурно-спортивную направленность: военно-спортивные игры «Зарница» и «Орленок», летние профильные военнопатриотические смены, соревнования по видам спорта. Одно из ключевых мероприятий - летняя и зимняя Спартакиады допризывной молодежи. Цель проведения Спартакиады - содействие духовно-нравственному и гражданскопатриотическому воспитанию молодежи допризывного возраста и ее подготовка к военной службе.

В соответствии с комплексной программой по подготовке молодежи к службе в Вооруженных Силах, рекомендованной Министерством обороны Российской Федерации, в субъектах организуются Дни призывника, соревнования по многоборью, спартакиады по боевым искусствам и другие спортивные соревнования патриотической направленности. Традиционно проводятся соревнования, посвященные Дням воинской славы и памятным датам России; памяти воиновинтернационалистов, погибших в локальных войнах и вооруженных конфликтах; памяти выдающихся российских спортсменов и тренеров.

Показательно, что к работе с молодежью допризывного и призывного возрастов привлекаются специалисты военного дела, кадровые военнослужащие, ветераны боевых действий. В организации таких мероприятий большую поддержку оказывают военные комиссариаты, спортивные клубы (комитеты) воинских частей, расположенных на территории, общественные организации и объединения (в том числе региональные отделения ДОСААФ России). Организация спортивных соревнований осуществляется во взаимодействии с федерациями по видам спорта.

Следует отметить, что патриотическое воспитание является важным составляющим элементом деятельности федераций по видам спорта при проведении спортивных мероприятий. Она направлена на развитие спортивных традиций, воспитание у спортсменов чувства уважения к стране, региону, коллективу, Государственному флагу и Государственному гимну Российской Федерации, ответственности за результаты выступлений на всероссийских и международных соревнованиях. В этой связи при проведении официальных физкультурных и спортивных мероприятий осуществляется подъем Государственного флага Российской Федерации, исполняется Государственный гимн Российской Федерации.

Новым направлением работы с молодежью допризывного и призывного возрастов является организация деятельности клубов военнопатриотического профиля. К занятиям в данных клубных формированиях привлекаются учащиеся средних и старших классов общеобразовательных школ, студенты учреждений высшего образования и средних специальных учебных заведений. Также при клубах военнопатриотической направленности действуют спортивные секции, воспитанники которых принимают активное участие в соревнованиях по военно-прикладным видам спорта, походах по местам боевой славы, а также историкокультурных акциях (трудовых десантах у мест захоронений участников Великой Отечественной войны 1941-1945 гг., мероприятиях военнопатриотической направленности музеев).

Одним из показателей реализации государственной программы «Патриотическое воспитание граждан Российской Федерации на 2016-2020 годы» является доля граждан Российской Федерации, выполнивших нормативы Всероссийского физкультурноспортивного комплекса «Готов к труду и обороне» (ВФСК ГТО), в общей численности населения, принимавшего участие в сдаче нормативов. ВФСК ГТО представляет собой программную и нормативную основу физического воспитания населения страны [15]. Комплекс является одним из механизмов вовлечения в физкультурно-спортивную деятельность различных поло-возрастных групп населения [5, 14]. В настоящее время на ближайшие четыре года утверждена новая редакция Государственных требований ВФСК ГТО, которая приводит их в соответствие с нормами Федерального Закона № 274 от 05.10.2015, Положения о комплексе ГТО (постановление Правительства Российской Федерации от 30.12.2015 № 1508), с Планом 
внедрения комплекса ГТО (распоряжение Правительства Российской Федерации от 30.06.2014 № 1165-р) и содержанием докладов Президенту Российской Федерации об уровне физической подготовленности населения за 2014 - 2016 гг. В регионах и МО работа в этом направлении проводится в соответствии с утвержденными Планами по поэтапному внедрению ВФСК ГТО (организация Центров тестирования; реализация комплекса физкультурно-спортивных мероприятий, в том числе летнего и зимнего фестивалей ВФСК ГТО).

$$
\text { Среди }
$$

мероприятий направленности необходимо отметить патриотические акции, посвященные памятным датам («Георгиевская ленточка», «Бессмертный полк», «Волонтеры Победы», Вахта памяти, Уроки Мужества и др.) (Таблицы 1-6).

\section{Conclusion}

1. В ходе исследования проведен анализ результатов мониторинга состояния патриотического воспитания детей, подростков и молодежи в Российской Федерации. Показано, что с позиции теории управления деятельность в сфере патриотического воспитания рассматривается как совокупность приемов и методов целенаправленного воздействия организационных структур государственного сектора, бизнес-сообщества и институтов гражданского общества (субъектов управления) на различные социально-демографические группы населения (объект управления) с целью достижения определенного результата (воспитание патриотизма).

2. Результаты проведения мониторинга совершенствование нормативно-правового, материально-технического, научнометодического, информационнопропагандистского обеспечения и др.; внедрение в деятельность работников организаций, задействованных в процесс патриотического воспитания детей, подростков и молодежи, современных форм, средств и методов воспитательной работы. Содержание форм работы с подрастающим поколением получено на основе систематизации традиционных и новых мероприятий военно-патриотической и спортивно-патриотической направленности в субъектах Российской Федерации и муниципальных образованиях. Успешно зарекомендовавшие себя в регионах формы и методы работы по патриотическому воспитанию учитывают динамично меняющуюся ситуацию, возрастные особенности граждан, а также необходимость активного межведомственного, межотраслевого взаимодействия и общественногосударственного партнерства.

Таблица 1

Формы работы по патриотическому воспитанию граждан в Центральном федеральном округе

\begin{tabular}{|c|c|}
\hline & \\
\hline & \multirow[b]{2}{*}{$\begin{array}{l}\text { Ключевое мероприятие - Спартакиада молодежи допризывного возраста (включает } \\
\text { соревнования по } 13 \text { спортивным, спортивно-техническим и военно-прикладным } \\
\text { видам). Спартакиада организуется совместно с Департаментом образования города } \\
\text { Москвы, Военным комиссариатом города Москвы, региональным отделением } \\
\text { ДОСААФ России города Москвы, префектурами административных округов города } \\
\text { Москвы. Церемония награждения призеров Спартакиады состоялась в Центральном } \\
\text { музее Великой Отечественной войны на Поклонной горе. }\end{array}$} \\
\hline & \\
\hline & \multirow{3}{*}{$\begin{array}{l}\text { Областной финал военно-патриотической игры «Зарница», областная Спартакиада } \\
\text { допризывной молодежи (Кубок Губернатора области по военизированной эстафете } \\
\text { среди военно-патриотических клубов и объединений в рамках Международных игр } \\
\text { АрМИ-2016); областные соревнования по полиатлону (в спортивных дисциплинах - } \\
\text { зимнее троеборье и летнее пятиборье); областные чемпионаты и первенства области } \\
\text { по видам спорта, культивируемым ДОСААФ России (авиамодельному спорту, } \\
\text { автомобильному спорту, спорту сверхлёгкой авиации, мотоциклетному спорт,, } \\
\text { пулевой стрельбе, радиоспорту, стрельбе из арбалета, судомодельному спорту); } \\
\text { городские и районные легкоатлетические эстафеты, посвященные Дню Победы; } \\
\text { спортивные турниры, массовые соревнования (в рамках празднования Дня защитника } \\
\text { Отечества). }\end{array}$} \\
\hline & \\
\hline & \\
\hline Вороне & $\begin{array}{l}\text { рганизовано тестирование допризывной молодежи и проведение районных } \\
\text { естивалей в рамках ВФСК ГТО, в том числе в рамках Всероссийской акции «Я }\end{array}$ \\
\hline
\end{tabular}




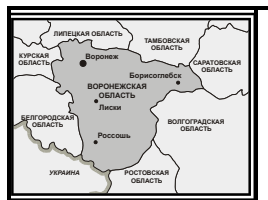

выбираю спорт». Ежегодно на регулярной основе проводятся спортивно-массовые мероприятия для молодежи, в том числе: Спартакиада среди молодёжи допризывного возраста и среди старшеклассников общеобразовательных организаций; первенства по различным видам спорта; спортивные соревнования, посвященные Дню Победы, Дню металлурга, Дню защитника Отечества. Ключевые мероприятия: областная Спартакиада допризывной молодежи; Спартакиада школьников; военно-спортивная игра «Марш бросок», приуроченная к празднованию Дня Победы в Великой Отечественной войне 1941-1945 гг.; областные соревнования по многоборью, включающему бег на дистанции 100 м, кросс, метание гранаты, подтягивание на перекладине и пулевую стрельбу; спортивные соревнования школьников «Президентские состязания» по 7 видам спорта (баскетболу, волейболу, футболу, русской лапте, легкоатлетическому кроссу, шахматам, легкоатлетическому четырёхборью).

Калужская область

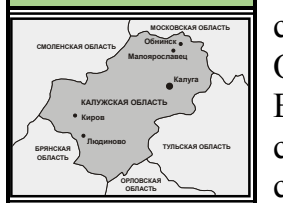
В области традиционно проводятся военно-спортивные игры для учащейся, студенческой и работающей молодежи («Зарница», «Орленок», «Риск», «Тактика»); соревнования и массовые спортивные праздники, посвященные Дню защитника Отечества и Дню Победы (в том числе показательные выступления для ветеранов Великой Отечественной войны, спортивные конкурсы «Веселые старты», спартакиады, блиц-турниры, легкоатлетические кроссы, товарищеские встречи, спортивно-патриотический праздник «Салют, Победа!»); Всероссийский турнир по волейболу, посвященный памяти сотрудников Управления внутренних дел; турнир по мини-футболу среди школьных команд, посвященный памяти Героя России Е. Клочкова (совместно с Калужским городским отделением ВОО ветеранов «БОЕВОЕ БРАТСТВО»).

Московская область

В соответствии с Календарным планом физкультурных и спортивных мероприятий Московской области традиционным стало проведение летней и зимней Спартакиад допризывной и призывной молодежи среди сборных команд муниципальных образований Московской области. По результатам соревнований финального этапа зимней Спартакиады допризывной и призывной молодёжи Московской области сформирована сборная команда Московской области, которая приняла участие в Армейских международных играх «АрМИ-2016».

Рязанская область

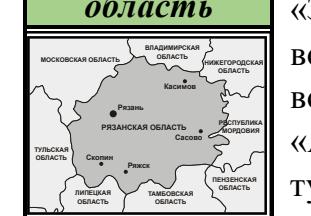
Совместно с военными комиссариатами проводятся военно-спортивные игры «Зарница», «Орленок», «Школа безопасности», «Новобранец», «Боевое братство»; военно-спортивные сборы «Дни призывника» на базе военно-спортивных лагерей и воинских частей; культурно-спортивные мероприятия «В армии служить почетно», «А ну-ка, парни!»; военизированные эстафеты для юношей - старшеклассников; туристические слеты; недельные сборы учащихся общеобразовательных школ допризывного и призывного возрастов на базе школ; смотры физической подготовки; соревнования по силовому троеборью, зимнему и летнему полиатлону, армрестлингу, гиревому спорту, стрельбе и кроссу; мероприятия в честь Дня защитника Отечества, Дня Победы. Новая форма работы с молодежью - проведение фестиваля подвижных игр, посвященного юбилейным датам.

Тамбовская область

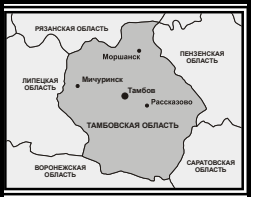

Наиболее крупные спортивные мероприятия в честь земляков-героев СССР, знаменитых спортсменов и тренеров: Всероссийский турнир по дзюдо, посвященный памяти Заслуженного тренера России (ЗТР) А.Ф. Малина; Всероссийский турнир по греко-римской борьбе, посвященный памяти чемпиона мира Е.Т. Артюхина; Мемориал экс-чемпиона России по шахматам, ЗТР В.С. Коренского; Мемориал олимпийца, мастера спорта (МС) СССР Н.Г. Дутова по легкоатлетическому кроссу; открытый областной турнир по футболу, посвященный памяти 3Т, ЗМС СССР В.М. Боброва; открытый областной турнир по грекоримской борьбе, посвященный памяти ЗТР А.А. Смолина; открытый областной турнир по волейболу, посвященный памяти Героя Советского Союза И.Т. Любушкина; областной турнир по волейболу, посвященный памяти Героя Советского Союза Г.А. Пономарева; областной турнир по волейболу, посвященный памяти Героя Советского Союза С.Н. Перекальского; открытый областной юношеский турнир по боксу, посвященный Дню Победы; областные соревнования по конькобежному спорту, посвященные памяти Героя Советского Союза Н. Кузнецова. Наиболее крупные военно-спортивные мероприятия: тактическая игра «Зарница», первенство и Спартакиада области по военно- 


\begin{tabular}{|l|l|}
\hline & прикладным видам спорта (полиатлону; пулевой стрельбе; парашютному, \\
авиамодельному видам спорта; рукопашному бою); соревнования по пожарно- \\
прикладному спорту на Кубок памяти погибших на пожаре В.П. Логунова и Ю.В. \\
Алферова. Мероприятия в рамках проведения месячника оборонно-массовой работы, \\
посвященного Дню защитника Отечества: лично-командное первенство области по \\
полиатлону среди допризывной молодежи; областные соревнования по пулевой \\
стрельбе; чемпионат и первенство области среди юношей 16-17 лет по армейскому \\
рукопашному бою; традиционный областной турнир по дзюдо среди юношей на \\
призы МС по дзюдо и самбо А.В. Юрина; Спартакиада среди допризывной молодежи.
\end{tabular}

\section{Формы работы по патриотическому воспитанию граждан в Северо-Западном федеральном} округе

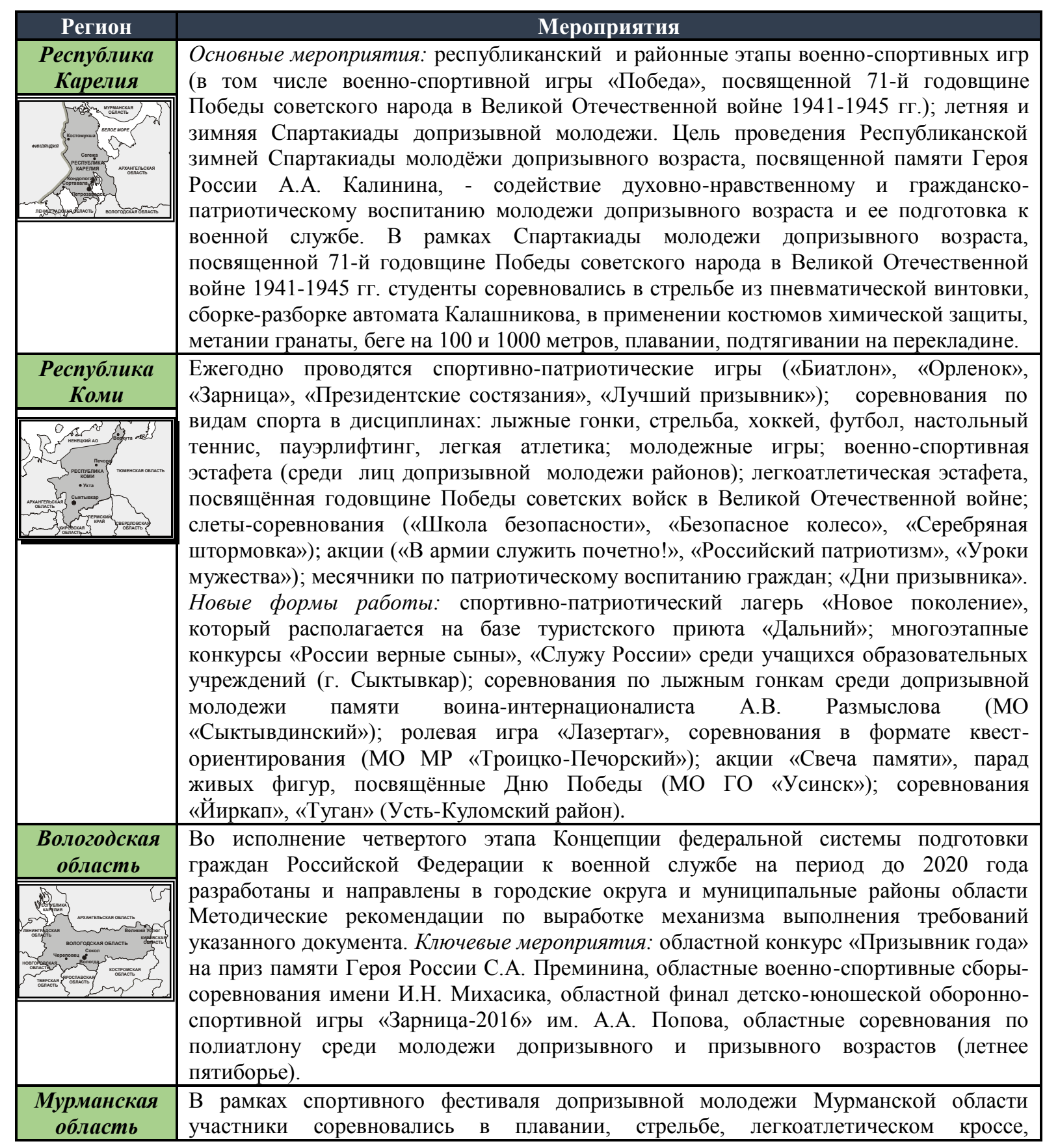




\section{Impact Factor:}

\begin{tabular}{|c|c|c|}
\hline ISRA (India) & $=1.344$ & SIS (USA) \\
\hline ISI (Dubai, UAI & 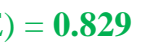 & РИНЦ $($ Russia $)=0$ \\
\hline GIF (Australia) & $=0.5$ & ESJI (KZ) \\
\hline II & $=1$. & SIIF \\
\hline
\end{tabular}

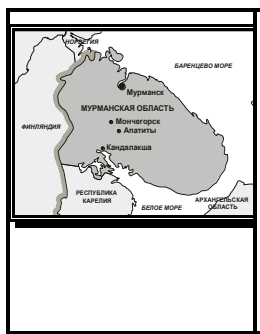

подтягивании на перекладине, военизированной эстафете. Основнье мероприятия: военно-спортивная игра «Зарница»; военно-спортивная игра «Победа»; «Школа безопасности»; «Безопасное колесо»; патриотические акции, посвященные памятным датам (Городской митинг на железнодорожном вокзале, посвященный Дню Победы; Уроки Мужества; Городская акция «Поздравь ветерана»; Тематическая выставка, посвященная Дню Победы в библиотеках школ; Вахта Памяти у памятника Неизвестному солдату; акции: «Георгиевская ленточка», «Поздравляем детей войны»; Вахта памяти «Героев помним имена!»).

\section{Формы работы по патриотическому воспитанию граждан в Приволжском и Северо-Кавказском федеральных округах}

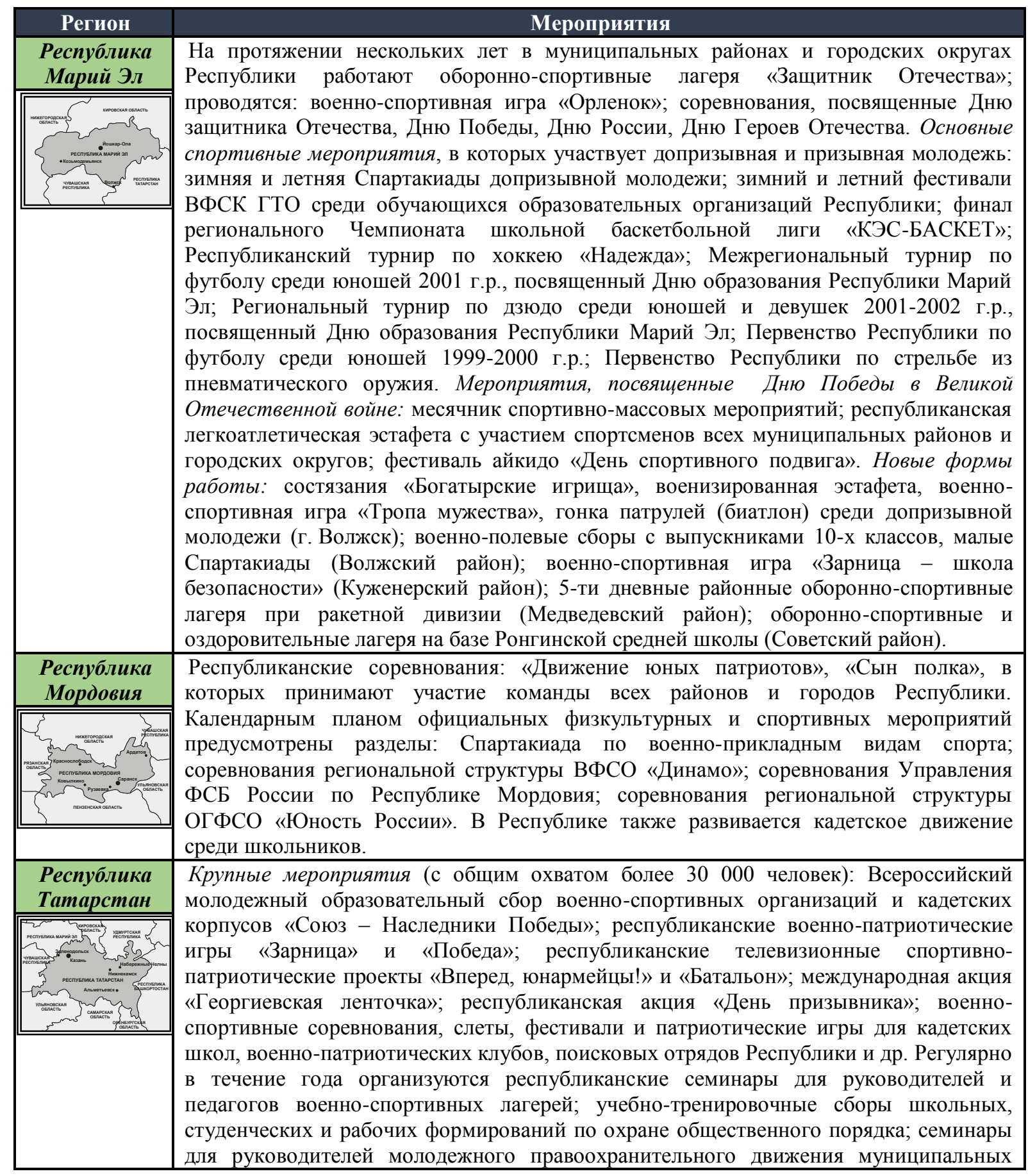

ISPC Generalization of scientific results, 


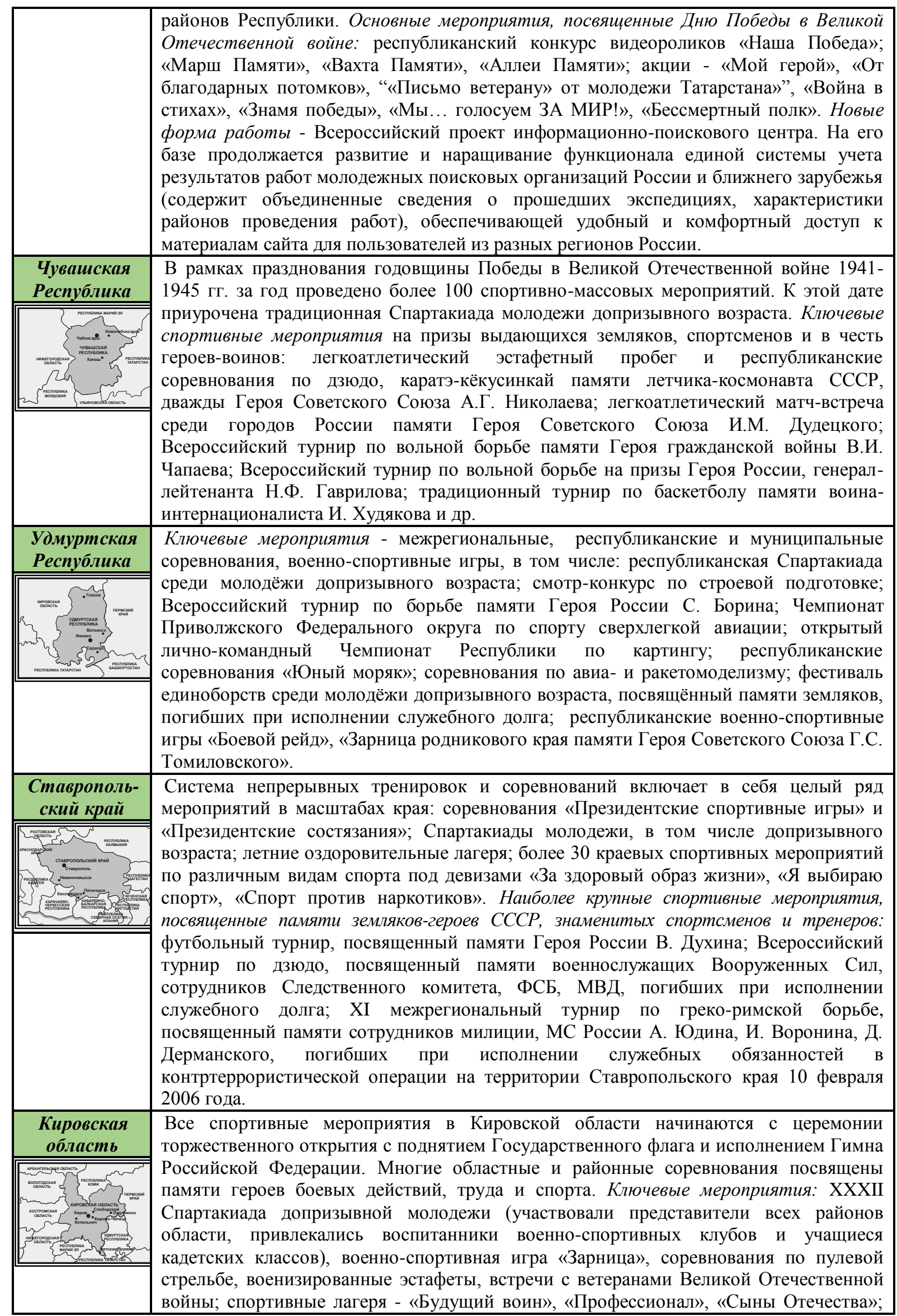




\begin{tabular}{|c|c|}
\hline & \\
\hline & \multirow{3}{*}{$\begin{array}{l}\text { С целью патриотического воспитания граждан на территории области проводятся: } \\
\text { областной спортивно-оздоровительный фестиваль школьников «Президентские } \\
\text { состязания»; Спартакиада школьников «Старты надежд»; Спартакиада средних } \\
\text { специальных учебных заведений «Юность Оренбуржья»; фестиваль студенческого } \\
\text { спорта; военно-спортивные соревнования «Зарница»; Спартакиада допризывной } \\
\text { молодежи Оренбургской области; соревнования по стрелковому спорту, авто- и } \\
\text { мотоспорту, радиоспорту; соревнования по судомодельному, авиамодельному и } \\
\text { автомодельному видам спорта (совместно с областным советом дОСААФ); месячник } \\
\text { оборонно-массовой и спортивной работы; социально-патриотическая акция «День } \\
\text { призывника»; экскурсии допризывной молодежи в воинские части, дислоцируемые на } \\
\text { территории области. }\end{array}$} \\
\hline & \\
\hline & \\
\hline & \multirow{3}{*}{$\begin{array}{l}\text { Комплекс физкультурных и спортивно-массовых мероприятий патриотической } \\
\text { направленности включает в себя как соревнования по военно-прикладным видам, } \\
\text { мероприятия, посвященные памятным датам, так и спортивно-зрелищные } \\
\text { мероприятия, в том числе: летний и зимний фестивали комплекса ГТО среди } \\
\text { обучающихся области; Спартакиаду боевых искусств «Непобедимая держава»; } \\
\text { фестиваль по парашютному многоборью среди молодежи допризывного возраста; } \\
\text { фестиваль военно-прикладных видов спорта; областную Спартакиаду среди молодежи } \\
\text { допризывного возраста; областную легкоатлетическую эстафету, посвященную } \\
\text { годовщине Победы и памяти братьев Володичкиных, погибших в Великой } \\
\text { Отечественной войне; Всероссийский турнир «Щит Невского;; областной } \\
\text { традиционный турнир по волейболу, посвященный годовщине вывода советских } \\
\text { войск и памяти погибших воинов в Демократической Республике Афганистан и др. } \\
\text { Соревнования, посвященные знаменитым спортсменам и тренерам Самарской } \\
\text { области: соревнования по лыжным гонкам «Гонка памяти»; открытый турнир } \\
\text { области памяти А. Козаева среди юношей и девушек } 14-15 \text { лет, юниоров и юниорок } \\
\text { 16-21 лет, мужчин и женщин по армспорту; первенство области среди юношей 13-14 } \\
\text { лет памяти ЗТР А.П. Бакуменко по боксу; ІV открытый турнир области среди юношей } \\
\text { и девушек до } 18 \text { лет памяти тренера П.И. Иванникова по дзюдо; открытые } \\
\text { соревнования области среди юношей и девушек до } 18 \text { лет «Легкоатлетический турнир } \\
\text { памяти тренеров»по легкой атлетике и др. }\end{array}$} \\
\hline & \\
\hline & \\
\hline & \multirow{3}{*}{$\begin{array}{l}\text { сновным мероприятием для молодёжи допризывного и призывного возрастов } \\
\text { зляется Спартакиада по зимним (лыжные гонки } 5 \text { км., стрельба из пневматической } \\
\text { интовки, подтягивание на перекладине) и летним (бег } 100 \text { м., кросс } 3000 \text { м., прыжки } \\
\text { места, метание гранаты, плавание } 50 \text { м.) видам спорта. Спартакиада проводится в } \\
\text { ва этапа: сначала во всех МО, а затем сборные команды МО (по } 5 \text { человек) } \\
\text { частвуют в финале Спартакиады в областном центре. В районах области } \\
\text { бразовательные учреждения организуют совместно с военными комиссариатами } \\
\text { вухнедельные военно-полевые сборы с учащимися } 10-x \text { классов. На базе } \\
\text { здоровительного лагеря «Юность» ежегодно проводится военно-спортивная игра } \\
\text { Орлёнок» среди учащихся учебных заведений начального и среднего } \\
\text { рофессионального образования. }\end{array}$} \\
\hline & \\
\hline & \\
\hline
\end{tabular}

Таблица 4

Формы работы по патриотическому воспитанию граждан в Уральском федеральном округе

\begin{tabular}{|c|c|}
\hline Регион & Мероприятия \\
\hline & \multirow{2}{*}{$\begin{array}{l}\text { Основные мероприятия: месячник оборонно-массовой и спортивной работы; } \\
\text { областной финал военно-спортивной игры «Победа»; областной фестиваль, } \\
\text { посвященный возрождению Всероссийского физкультурно-спортивного комплекса } \\
\text { ГТО среди населения Курганской области; военно - спортивная игра «Зарница»; } \\
\text { Спартакиада допризывной молодежи Курганской области по военно-прикладным } \\
\text { видам спорта. В МО - мероприятия по видам спорта, посвященные Дню защитника } \\
\text { Отечества и годовщине Победы в Великой Отечественной войне. }\end{array}$} \\
\hline & \\
\hline $\begin{array}{c}\text { Свердловская } \\
\text { область }\end{array}$ & $\begin{array}{l}\text { В МО Свердловской области проводятся месячники, посвящённые Дню защитника } \\
\text { Отечества, Дню Победы в Великой Отечественной Войне, Дню воинской Славы, в }\end{array}$ \\
\hline
\end{tabular}




\begin{tabular}{l|l} 
рамках которых организуются соревнования по спортивному многоборью, силовым \\
видам спорта; военно-спортивные эстафеты; спортивные игры среди учащихся \\
общеобразовательных школ; военно-полевые сборы старшеклассников; акции - «Вахта \\
памяти», «Пост № 1», «Ветеран», «Милосердие». Мероприятия городского масштаба, \\
направленные на формирование духа патриотизма среди молодежи: городские \\
тематические выставки, Дни открытых дверей музеев города, акции и флешмобы в дни \\
памятных дат, военно-спортивные игры «Зарница» иБогатырские игры», смотры- \\
конкурсы юнармейских отрядов, туристические слеты, экологические рейды, \\
фестивали патриотической песни, слеты волонтеров и летних молодежных трудовых \\
бригади др.
\end{tabular}

Формы работы по патриотическому воспитанию граждан в Сибирском федеральном округе

\begin{tabular}{|c|c|}
\hline H & Мероприятия \\
\hline & $\begin{array}{l}\text { Ежегодно проводится Спартакиада молодежи Республики Хакасия допризывного } \\
\text { возраста. Мероприятия по реализации ВФСК ГТО: муниципальные этапы летнего и } \\
\text { зимнего фестивалей ВФСК ГТО, по итогам которых были сформированы } \\
\text { команды, принявшие участие в региональных этапах зимних и летних фестивалей; } \\
\text { фестиваль ГТО среди государственных образовательных организаций (на базе } \\
\text { Федерального государственного бюджетного образовательного учреждения высшего } \\
\text { образования «Хакасский государственный университет имени Н.Ф. Катанова»). }\end{array}$ \\
\hline & $\begin{array}{l}\text { Tрадищионные мероприятия для молодежи допризывного и призывного возрастов: } \\
\text { краевые соревнования «Служить России любой из нас готов!», посвященные Дню } \\
\text { защитника Отечества; Спартакиада молодежи допризывного возраста; военно- } \\
\text { патриотический фестиваль «Сибирский щит». С } 2014 \text { года в рамках фестиваля } \\
\text { проводится военно-патриотическая игра, направленная на формирование у молодежи } \\
\text { навыков военно-прикладных и технических видов спорта, ориентирования в условиях } \\
\text { чрезвычайных ситуаций; положительного отношения и интереса к службе в } \\
\text { Вооруженных Силах Российской Федерации, спорту, здоровому образу жизни. }\end{array}$ \\
\hline $\begin{array}{c}\text { Кемеровская } \\
\text { область }\end{array}$ & $\begin{array}{l}\text { Ключевые мероприятия среди учащейся молодежи призывного и допризывного } \\
\text { возраста в городах и районах области: соревнования по техническим видам спорта, } \\
\text { проводимые в честь Дня защитника Отечества; слеты призывников, Спартакиады } \\
\text { допризывной и призывной молодежи Кемеровской области; месячники оборонно- } \\
\text { массовой и спортивной работы среди допризывной молодежи. Традиционно } \\
\text { проводятся соревнования, посвященные Дням воинской славы и памятным датам } \\
\text { России, памяти воинов-интернационалистов, погибших в локальных войнах и } \\
\text { вооруженных конфликтах. В МО области реализуются собственные программы по } \\
\text { патриотическому воспитанию граждан. }\end{array}$ \\
\hline
\end{tabular}


Таблица 6 Формы работы по патриотическому воспитанию граждан в Дальневосточном федеральном округе

\begin{tabular}{|c|c|}
\hline & \\
\hline & \multirow[b]{2}{*}{$\begin{array}{l}\text { В целях допризывной подготовки молодежи к военной службе организованы } \\
\text { муниципальные этапы военно-спортивной игры «Зарница» («Победа»); проведен } \\
\text { краевой финал военно-спортивной игры. Традищионные мероприятия: соревнования } \\
\text { «Школа безопасности» и полевые лагеря «Юный спасатель» в рамках деятельности } \\
\text { ВДЮОД «Школа безопасности»; акция «К защите Родины готов!» по военно- } \\
\text { прикладным видам спорта; региональный этап Всероссийских соревнований } \\
\text { «Призывники России» [по следующим дисциплинам - стрельба из малокалиберной } \\
\text { винтовки, бег } 100 \text { м, бег } 1000 \text { м (девушки), бег } 2000 \text { м (юноши), сборка-разборка } \\
\text { автомата, преодоление полосы препятствий, метание гранаты на дальность, } \\
\text { страйкбол]; краевой этап военно-спортивной игры «Казачий сполох»; летний и } \\
\text { зимний фестивали ВФСК ГТО. Особое внимание уделяется мероприятиям, } \\
\text { связанным с днями воинской славы советского народа в Великой Отечественной } \\
\text { войне 1941-1945 гг. }\end{array}$} \\
\hline & \\
\hline & \multirow{3}{*}{$\begin{array}{l}\text { С целью духовно-нравственного и патриотического воспитания молодежи проводятся } \\
\text { соревнования, посвященные памятным и знаменательным датам, знаменитым } \\
\text { соотечественникам и землякам. Ключевые мероприятия: соревнования по видам } \\
\text { спорта в городских округах и муниципальных районах края; фестивали допризывной } \\
\text { молодежи (краевой финал фестиваля выявляет лучшую команду МО); краевой этап } \\
\text { военно-спортивной игры «Победа» и краевой финал комбинированной военно- } \\
\text { спортивной игры «Патриот», приуроченные к } 71 \text {-й годовщине Победы в Великой } \\
\text { Отечественной войне 1941-1945 гг. Новая организационная форма: профильный } \\
\text { краевой военизированный дальний шлюпочный поход «Парус Отечесвва (г. } \\
\text { Комсомольск-на-Амуре - с. Казакевичево- г. Хабаровск- с. Нижнетамбовское - г. } \\
\text { Комсомольск-на-Амуре); краевой конный фестиваль (организатор - спортивно- } \\
\text { оздоровительный центр «Мустанг»). Молодежь принимает активное участие в } \\
\text { реализуемых на территории края федеральных и краевых проектах: «Волонтеры } \\
\text { Победы», «Бессмертный полк», «Георгиевская ленточка» и др. } \\
\end{array}$} \\
\hline & \\
\hline & \\
\hline & \multirow{2}{*}{$\begin{array}{l}\text { Ключевые мероприятия: Спартакиады молодежи допризывного и призывного } \\
\text { возрастов, областная военно-патриотическая смена «Призывники Амура; II } \\
\text { Спартакиада региональных отделений дОСААФ Амурской области (соревнования по } \\
\text { пулевой стрельбе; мотоциклетному, автомобильному, самолетному, парашютному, } \\
\text { судомодельному, авиамодельному видам спорта; рукопашному бою). Новые формы } \\
\text { мероприятий в отдельных МО: спортивно-патриотическая игра «Эстафета Подвига»» } \\
\text { (Бурейский район); военно-спортивная эстафета «Чудиновский бой» (Свободненский } \\
\text { район); военно-спортивная игра «Штурм высоты» (Серышевский район); военно- } \\
\text { патриотическая спортивная игра «Штурм крепости» (г. Свободный); военно- } \\
\text { спортивные мероприятия «Один день в армии», «Испытание солдата» (г. Белогорск). }\end{array}$} \\
\hline & \\
\hline
\end{tabular}

References:

1. Gosudarstvennaja «Patrioticheskogo Rossijskoj Federacii na 2016-2020 gody» [Jelektronnyj resurs]. Available: http://docs.cntd.ru/document/420327349 (Accessed: 15.02.2017).

2. Izaak S.I. (2005) Fizicheskaja kul'tura i sport v razvitii zdorov'eformirujushhih $\mathrm{i}$ zdorov'esberegajushhih tehnologij, nravstvennom i patrioticheskom vospitanii: materialy Vserossijskoj nauchno-prakticheskoj konferencii «Grazhdanskoe i patrioticheskoe vospitanie molodezhi sredstvami fizicheskoj kul'tury i sporta v sovremennyh uslovijah». Ulan-Udje: VSGTU, 2005. p. 40-46.

3. Izaak S.I., Indreev M.H., Puhovskaja M.N. (2005) Upravlenie fizkul'turno-ozdorovitel'noj 
rabotoj: uchebno-metodicheskoe posobie / Pod obshh. red. S.I. Izaak. M., 2005. 96 p.

4. Izaak S.I. (2013) Koncepcija monitoringa sostojanija fizicheskogo zdorov'ja naselenija, fizicheskogo razvitija i fizicheskoj podgotovlennosti detej, podrostkov i molodezhi Respubliki Kazahstan // Sport: jekonomika, pravo, upravlenie. 2013. № 3. p. 41-46.

5. Izaak S.I. (2015) Realizacija Ukaza Prezidenta Rossijskoj Federacii «O Vserossijskom fizkul'turno-sportivnom komplekse «Gotov $\mathrm{k}$ trudu i oborone» (GTO) // Sport: jekonomika, pravo, upravlenie. 2015. № 2. p. 12-14.

6. Izaak S.I. (2017) Celevye pokazateli realizacii Strategii razvitija fizicheskoj kul'tury i sporta v Rossijskoj Federacii na period do 2020 goda // Nauchnyj forum: Innovacionnaja nauka: sb. st. po materialam VI mezhdunar. nauch.- prakt. konf. № 5(6). M., 2017. p. 65-69.

7. Izaak S.I. (2017) Realizacija Strategii razvitija fizicheskoj kul'tury i sporta v Rossijskoj Federacii na period do 2020 goda: sostojanie i prioritety razvitija [Jelektronnyj resurs]. Available:

http://www.myshared.ru/slide/1359214/ (Accessed: 19.10.2017).

8. Izaak S.I., Molodenkov D.A. (2011) Monitoring investicionnoj privlekatel'nosti regionov // Vestnik Samarskogo municipal'nogo instituta upravlenija. 2011. № 3. p. 79-84.

9. Izaak S.I., Rodionov S.I. (2011) Monitoring social'no-jekonomicheskogo sostojanija municipal'nogo obrazovanija // Vestnik Samarskogo municipal'nogo instituta upravlenija. 2011. № 4. p. 104-110.

10. Lukinova I.A. (2013) Mesto i rol' rossijskogo patriotizma $\mathrm{v}$ sovremennom obshhestve: avtoref. diss. ... kand. filos. nauk. Stavropol', 2013. 24 p.

11. Macievskaja G.A. (2016) Ob osnovah gosudarstvennoj politiki patrioticheskogo vospitanija v sovremennoj Rossii // Nauchnye vedomosti Belgorodskogo gosudarstvennogo universiteta. Serija: Filosofija. Sociologija. Pravo. 2016. T. 38. № 24 (245). p. 164-168.

12. Mironov V.D., Izaak S.I., Shhadilova I.S. (2017) Osobennosti upravlenija processom formirovanija lokal'nogo patriotizma $u$ studentov sredstvami fizicheskoj kul'tury i sporta: materialy XXI Vserossijskoj nauchnoprakticheskoj konferencii «Sovremennye problemy fizicheskoj kul'tury i sporta». Habarovsk, 2017.
13. Panasjuk T.V., Izaak S.I., Komissarova E.N. (2005) Antropologicheskij monitoring doshkol'nikov: ucheb. posobie. M., 2005. 110 p.

14. Parshikova N.V. (2016) Obrashhenie rukovoditelja Koordinacionnoj komissii Ministerstva sporta Rossijskoj Federacii po vvedeniju i realizacii Vserossijskogo fizkul'turno-sportivnogo kompleksa «Gotov $\mathrm{k}$ trudu i oborone» (GTO) // Adaptivnaja fizicheskaja kul'tura. 2016. № 1 (65). p. 2.

15. Parshikova N.V., Izaak S.I., Malits V.N. (2017) Strategicheskie prioritety gosudarstvennoj politiki v oblasti massovogo sporta // Uchenye zapiski universiteta im. P.F. Lesgafta. 2017. № 6 (148). p. 167-171.

16. (2017) Federal'nyj zakon ot 12.01.1995 № 5-FZ (red. ot 30.10.2017) «O veteranah» [Jelektronnyj resurs]. - Available: http://www.consultant.ru/document/cons_doc LAW 5490/ (Accessed: 9.08.2017).

17. (2014) Federal'nyj zakon ot 13.03.1995 № 32FZ (red. ot 01.12.2014) «O dnjah voinskoj slavy i pamjatnyh datah Rossii» [Jelektronnyj resurs]. $\quad-\quad$ Available: http://www.consultant.ru/document/cons_doc LAW 5978/ (Accessed: 9.08.2017).

18. (2014) Federal'nyj zakon ot 19.05.1995 № 80FZ (red. ot 04.11.2014) «Ob uvekovechenii Pobedy sovetskogo naroda v Velikoj Otechestvennoj Vojne 1941-1945 godov»» [Jelektronnyj resurs]. - Available: http://www.consultant.ru/document/cons_doc LAW 6643/ (Accessed: 9.08.2017).

19. (2017) Federal'nyj zakon ot 28.03.1998 № 53FZ (red. ot 27.11.2017) «O voinskoj objazannosti i voennoj sluzhbe» [Jelektronnyj resurs]. $\quad-\quad$ Available: http://www.consultant.ru/document/cons_doc LAW_18260/ (Accessed: 9.08.2017).

20. (2017) Federal'nyj zakon ot 04.12.2007 № 329FZ (red. ot 26.07.2017) «O fizicheskoj kul'ture i sporte v Rossijskoj Federacii» [Jelektronnyj resurs]. Available: http://www.kremlin.ru/acts/bank/26631 (Accessed: 15.02.2017).

21. Shahraj S.M., Izaak S.I. (2013) Analiz realizacii Strategii razvitija fizicheskoj kul'tury i sporta v Rossijskoj Federacies an period do 2020 g. v regional I municipal'nyh obrazovanijah // Sport: jekonomika, pravo, upravlenie. 2013. № 4. p. 11-14. 